\title{
Hypophysitis: Evaluation and Management
}

\author{
Alexander Faje(i)
}

\begin{abstract}
Hypophysitis is the acute or chronic inflammation of the pituitary gland. The spectrum of hypophysitis has expanded in recent years with the addition of two histologic subtypes and recognition as a complication of treatment with immune checkpoint inhibitors. Despite the increased number of published cases, the pathogenesis of hypophysitis is poorly understood, and treatment strategies are diverse and controversial. The diagnosis of hypophysitis generally requires histopathologic confirmation. The presentation and clinical course of hypophysitis varies. Hypophysitis can resolve spontaneously, relapse may occur, and some cases can be refractory to treatment.
\end{abstract}

Keywords: Hypophysitis, Hypopituitarism, Diabetes insipidus

Abbreviations: ADCC, Antibody-dependent cell-mediated cytotoxicity; CTLA-4, Cytotoxic T-lymphocyte antigen-4; ECD, Erdheim-Chester disease; IIF, Indirect immunofluorescence; LCH, Langerhans cell histiocytosis; MRI, Magnetic resonance imaging; PD-1, Programmed cell death 1

\section{Background}

Hypophysitis has gained greater clinical recognition over time. Several histologic variants and causative agents have been identified. Although hypophysitis remains a rare diagnosis, the number of published cases has increased substantially and expanded to involve a more gender and age diverse population. The quantity and quality of available information is limited, however, and consensus, especially regarding treatment, has been elusive. Prospective studies are necessary to better define optimal diagnostic and management strategies.

Hypophysitis can be classified according to etiology, morphology, and/or histopathology. Etiology refers to primary or secondary cases of hypophysitis. Primary hypophysitis refers to isolated inflammation of the pituitary not associated with medications, systemic inflammatory disorders, infections, or other diseases. Secondary hypophysitis includes cases associated with immunotherapy (interleukin 2, interferon, and medications targeting cytotoxic T-lymphocyte antigen-4 [CTLA-4] or programmed cell death 1 [PD-1]) [1-6], rupture of sellar cysts (Rathke's cleft cysts and craniopharyngiomas), and rarely, pituitary adenomas [7-15]. Some authors utilize the term secondary hypophysitis more broadly and also include systemic inflammatory processes which may

Correspondence: afaje@partners.org

Neuroendocrine Unit, Massachusetts General Hospital and Harvard Medical School, 55 Fruit Street, Boston, MA 02114, USA involve the pituitary gland (such as sarcoidosis, Wegener's granulomatosis, Crohn's disease, Takayasu's arteritis, Cogan's syndrome), inflammatory cell proliferative disorders (Langerhans cell histiocytosis $[\mathrm{LCH}]$ and Erdheim-Chester disease [ECD]), infections (tuberculosis, syphilis, Whipple's disease, mycoses), and tumor-associated inflammatory infiltrate (germinoma).

Morphologic categorization is made according to whether inflammation involves the anterior pituitary gland (adenohypophysitis), posterior gland and stalk (infundibuloneurohypophystis), or entire gland (panhypophysitis).

Histologic subtypes of hypophysitis include the following: lymphocytic, granulomatous, xanthomatous, and plasmacytic (Table 1). Occasionally, mixed histology is encountered [16]. Necrotizing hypophysitis has also been proposed as an additional variant, but it has only been reported in 3 cases $[17,18]$. Lymphocytic hypophysitis is characterized by diffuse lymphocyte infiltration (primarily $\mathrm{T}$ cells) of the pituitary gland. Lymphoid follicles can be observed and occasional plasma cells, eosinophils, and fibroblasts may also be present [19]. Granulomatous hypophysitis shows large numbers of multinucleated giant cells and histiocytes with granuloma formation $[20,21]$. Xanthomatous hypophysitis demonstrates lipid-laden "foamy" histiocytes without the presence of granulomas [22, 23]. Plasmacytic hypophysitis, also termed IgG4-related hypophysitis, has extensive gland infiltration by plasma cells with a high degree of IgG4 
Table 1 Histologic subtypes of hypophysitis and patient characteristics

\begin{tabular}{llll}
\hline & $\begin{array}{l}\text { Gender } \\
\text { predominance }\end{array}$ & $\begin{array}{l}\text { Association with } \\
\text { pregnancy }\end{array}$ & $\begin{array}{l}\text { Mean age of } \\
\text { presentation }\end{array}$ \\
\hline Lymphocytic & Female, 3:1 & Yes & 4th decade \\
Granulomatous & Female, 3:1 & No & 5th decade \\
Xanthomatous & Female, 3:1 & No & 4th decade \\
$\begin{array}{l}\text { Plasmacytic } \\
\text { (lgG4-related) }\end{array}$ & Male, 2:1 & No & 7th decade \\
\hline
\end{tabular}

Mixed histology is observed occasionally, and necrotizing hypophysitis has been proposed as an additional category. Data abstracted from references $[20,23,25,27,66]$

positivity [24-26]. Pituitary gland fibrosis and atrophy may occur in later stages of these hypophysitis variants.

Precise usage of the term hypophysitis is important. Loose or inconsistent application (such as grouping germinoma-associated inflammation and primary lymphocytic hypophysitis) can cause reader confusion and suggest inappropriate treatments rather than provide diagnostic clarification. Unfortunately, such cases have been mixed with primary hypophysitis in some review paper data sets [27]. Unless otherwise stated, further discussion in this manuscript will focus on patients with primary hypophysitis. A caveat exists for IgG4-related hypophysitis, which is often a manifestation of systemic disease with involvement of multiple organs. Most authors have not grouped IgG4-related hypophysitis in the general category of secondary hypophysitis, though it may be reasonable to do so. This manuscript does include an examination of IgG4-related hypophysitis. Given the expanding applications of immune checkpoint inhibitors and increasing frequency of this form of secondary hypophysitis, brief discussion will also be devoted to immunotherapyassociated hypophysitis.

\section{Epidemiology}

The annual incidence of hypophysitis is estimated to be 1 in 7-9 million. Hypophysitis accounts for approximately $0.4 \%$ of pituitary surgery cases (based on a group of large surgical series totaling nearly 10,000 procedures at 5 centers) [28-32].

Lymphocytic hypophysitis was first reported in 1962 [33], and granulomatous hypophysitis was described in the early twentieth century $[34,35]$. The first cases of xanthomatous hypophysitis and IgG4-related hypophysitis were published more recently in 1998 and 2004, respectively [22, 36].

Lymphocytic hypophysitis is the most common histologic variant, with over 390 cases reported. Granulomatous hypophysitis is the next most frequent subtype, followed by xanthomatous and IgG4-related hypophysitis [25]. Lymphocytic hypophysitis was initially thought to occur only in adult women, but cases were subsequently described in men [37] and children [3840]. Lymphocytic hypophysitis does occur more frequently in women compared to men (approximately 3:1 ratio of cases [27]), in large part because of its association with pregnancy [41]. Though recent series have not shown as strong a relationship $[42,43]$, the majority of cases among reproductive-aged women appear to occur during the end of pregnancy or the first few months after delivery [16, 27]. The incidence of lymphocytic hypophysitis peaks during the fourth decade of life and is uncommon in children and the elderly.

Granulomatous and xanthomatous hypophysitis also occur more frequently in women (approximately 3:1 ratio of cases), but neither form is linked with pregnancy. Xanthomatous hypophysitis and lymphocytic hypophysitis have a similar mean age of presentation, but granulomatous hypophysitis is diagnosed more often at a slightly later timepoint in the fifth decade $[20,23]$. IgG4-related hypophysitis occurs more frequently in men and tends to develop at a more advanced age in the seventh decade of life. IgG4-related hypophysitis also does not have an association with pregnancy $[25,26]$.

Immunotherapy-associated hypophysitis occurs in up to $10-15 \%$ of patients receiving agents targeting CTLA4 , on average 2-3 months after starting therapy. Older age and male gender may be risk factors for the development of hypophysitis with anti-CTLA-4 medications. Hypophysitis is comparatively rare following treatment with anti-PD-1 agents. Hypophysitis has also been reported very rarely after treatment with interleukin 2 and interferon [6].

\section{Clinical presentation}

Patients with hypophysitis present with symptoms related to mass effect from pituitary gland enlargement and pituitary/hypothalamic dysfunction. Headache is the most common presenting symptom, occurring in about half of patients. Visual symptoms due to compression of the optic nerves and/or cranial nerves III, IV, and VI in the cavernous sinuses can occur in a substantial minority of patients [16, 27, 42]. Cavernous carotid artery occlusion is a rare complication of hypophysitis [31, 44-46]. The onset of symptoms, including headache, can be insidious, subacute, or acute even mimicking apoplexy $[42,47,48]$.

The majority of patients with hypophysitis have multiple anterior pituitary hormone deficiencies, and anterior panhypopituitarism is not uncommon. The severity of hormone deficiencies may appear to be out of proportion to radiographic findings. Serum prolactin levels may be low, normal, or elevated [16, 19, 27, 42]. Unlike what is observed in clinically nonfunctioning pituitary adenomas [49], there is not a clear hierarchy of anterior pituitary 
hormone deficiencies in hypophysitis patients. Hypothalamic pituitary adrenal axis dysfunction is frequently present. Diabetes insipidus is also common and may occur in up to half of patients $[16,19,27,42]$.

Immunotherapy-associated hypophysitis often presents with headache and anterior hypopituitarism. The degree of pituitary enlargement is typically mild, and compression of the optic apparatus is very rare. Unlike other forms of hypophysitis, diabetes insipidus is extremely unusual in patients with immunotherapy-associated hypophysitis [6].

\section{Diagnosis}

The differential diagnosis for primary hypophysitis is broad, and ultimately histopathology (which is not always possible to obtain) is required for confirmation. Alternative diagnostic considerations include anatomic variants (a small/narrow sella turcica with specious pituitary enlargement) and congenital malformations, pituitary hyperplasia, solid and cystic sellar/suprasellar lesions (such as pituitary adenomas with or without apoplexy, Rathke's cleft cyst, craniopharyngioma, pituitcyte-derived tumors, hamartoma, dermoid or epidermoid cyst, gangliocytoma, lipoma), malignancies (central nervous system germinoma, lymphoma, glioma, metastatic lesions, LCH, ECD), systemic inflammatory disorders (sarcoidosis, Wegener's granulomatosis, Crohn's disease, Takayasu's arteritis, Cogan's syndrome), and infections (tuberculosis, syphilis, Whipple's disease, mycoses). A thorough evaluation is necessary to accurately diagnose hypophysitis, especially in the absence of tissue confirmation. In the largest series of pituitary stalk lesions published to date, only $4 \%$ of pathology-proven diagnoses represented primary hypophysitis (and only one-third of cases were inflammatory disorders of any type). Significantly, more than half of the confirmed stalk lesions represented neoplastic processes, and half of these cases were metastatic lesions [50]. A positive response to glucocorticoids, often interpreted as supporting evidence for hypophysitis, is not specific for inflammatory processes. Glucocorticoids are part of standard treatment regimens for $\mathrm{LCH}$ and ECD [51, 52], and temporary treatment responses can be observed in lymphoma and intracranial germinomas [53-55]. Treatment responses in the latter are likely due to effects on tumor infiltrating lymphocytes. This lymphoid infiltrate can be significant enough that misdiagnosis can even occur after tissue biopsy due to sampling error [56-58].

Certain radiology findings may support a diagnosis of hypophysitis. These imaging characteristics include homogenous enhancement of the pituitary, diffuse symmetric gland enlargement, midline stalk thickening, absence of a posterior pituitary bright spot, normal sellar size, dural thickening, parasellar T2-weighted hypointensity, and parasellar mucosal thickening. One group described a radiologic scoring model with an apparent high ability to distinguish hypophysitis from pituitary adenomas [59]. This model was not assessed for its discriminatory value against other potential diagnoses. Ultimately, radiologic findings are not specific for hypophysitis, especially compared to nonadenomatous sellar lesions.

Diagnostic criteria have been proposed for IgG4-related hypophysitis. These include the following: 1) pituitary histopathology demonstrating mononuclear infiltration with greater than 10 IgG4-positive cells per highpowered field, 2) magnetic resonance imaging (MRI) showing a sellar mass and/or stalk thickening plus biopsy-proven IgG4-related disease at another tissue site, or 3) sellar mass and/or stalk thickening plus a serum IgG4 level $>140 \mathrm{mg} / \mathrm{dl}$ and a radiologic and clinical response to treatment with glucocorticoids [24]. These proposed criteria may be inadequate in some circumstances. Recent studies have shown that neither serum IgG4 levels [60, 61] nor IgG4-positive tissue staining [62-65] are necessarily sensitive nor specific for IgG4-related disease. According to more recent international consensus criteria, diagnoses of IgG4-related disease are primarily based upon pathology demonstrating 2 of 3 major histopathological features (dense lymphoplasmacytic infiltrate, storiform fibrosis [a cartwheel or whirled pattern of fibrosis, at least focally], and obliterative phlebitis) with appropriate clinicopathologic correlation. IgG4 serum levels and tissue staining have important secondary roles [66]. Published cases of IgG4-related hypophysitis typically do not comment on the presence or absence of such histologic features [26]. When it is described, storiform fibrosis has been reported in some [67] but not all cases of IgG4-related hypophysitis [68] following tissue analysis. Obliterative phlebitis has not been reported in any case of IgG4-related hypophysitis. As Ngaosuwan et al. noted, the diagnosis of IgG4-related hypophysitis is difficult without the presence of other organ involvement [69]. Although only a minority of reported IgG4-related hypophysitis cases have included histopathology, almost all patients had other organ involvement [70].

No case of immunotherapy-associated hypophysitis has been confirmed by pituitary gland biopsy. Diagnoses are established clinically based upon the close temporal relationship of immunotherapy treatment and the development of hypopituitarism with reversible pituitary enlargement $[6,71]$. The relationship of lymphocytic hypophysitis with pregnancy $[27,41]$ may also allow a clinical diagnosis to be made with a reasonable degree of confidence in some pregnant or early postpartum women without tissue confirmation when appropriate imaging and biochemical findings are present with an otherwise negative thorough diagnostic evaluation. 
Patient demographics and coexistent medical conditions may also help focus diagnostic considerations. For example, intracranial germinomas have a peak incidence in the second decade of life and are extremely rare after the age of 30 [72]. LCH can be diagnosed at any age, but the incidence of this disease progressively declines throughout life [73, 74].

Given the broad differential diagnosis for hypophysitis, caution and close follow up is strongly advised for the treatment of presumed cases lacking histopathologic confirmation.

\section{Treatment}

No prospective controlled studies have examined the treatment of hypophysitis, and a limited number of cases detail the natural history of untreated disease. Available retrospective data sets are confounded by reporting and treatment selection biases and likely encompass a heterogeneous group of diseases due to the lack of histologic confirmation in many cases and variable clinical evaluation. Medical therapies differ significantly by the type of agent, dosage, and duration of treatment.

Symptoms from mass effect, such as optic nerve compression and other cranial nerve palsies, and severe headache are general indications for the treatment of hypophysitis (Fig. 1). Practice patterns vary for less clinically severe cases. It is unclear whether treatment with immune suppressing medications improves pituitary function outcomes compared to supportive therapy.

Spontaneous resolution of pituitary enlargement has been observed in a number of published cases of hypophysitis [19]. One group recently reported regression of radiologic findings in 15/15 patients receiving supportive therapy [43]. A large recent retrospective review of hypophysitis cases in Germany noted radiologic improvement or stability in 16/22 cases without active treatment [75]. Pituitary surgery (gross total resection or partial resection) and glucocorticoid therapy appeared to be somewhat more effective at mass reduction in that study. Surgery (generally patients undergoing gross total resection) was associated with less improvement and greater loss of pituitary function. Patients receiving glucocorticoid therapy had a significant risk of relapsing pituitary enlargement and experienced frequent side effects from treatment. Approximately one-quarter of patients receiving supportive therapy demonstrated improvement in pituitary function, and $82 \%$ of that group had stable or improved function. Similar results were reported in the patients treated with pharmacologic doses of glucocorticoids. Headache resolution was similar in all three groups [75]. Comparable rates of pituitary function recovery were reported following supportive therapy by Khare et al. [43]. A review by Lupi et al. suggested that pituitary function improvement may occur in approximately one-half of patients treated with glucocorticoids. Importantly, histopathology was available in only $22 \%$ of these patients [76]. Similarly, a minority of patients had tissue confirmation in the study from Germany. Moreover, evaluation for secondary causes of hypophysitis was limited in the majority of those patients [42, 75]. Limited clinical evaluations were also frequent in the largest review of granulomatous hypophysitis cases [20].

Other immunosuppressive agents such as methotrexate, azathioprine, rituximab, infliximab, cyclosporine, and mycophenolate mofetil have been utilized in a small number of patients with hypophysitis [75-82]. Treatment with stereotactic radiosurgery and fractionated radiotherapy has been reported in a few patients, typically with refractory disease. Radiation dosages ranged from low levels to higher amounts used to treat pituitary adenomas $[31,83,84]$.

Patients with immunotherapy-associated hypophysitis have been treated with physiologic to high-dose glucocorticoids. Although it is unclear whether pharmacologic

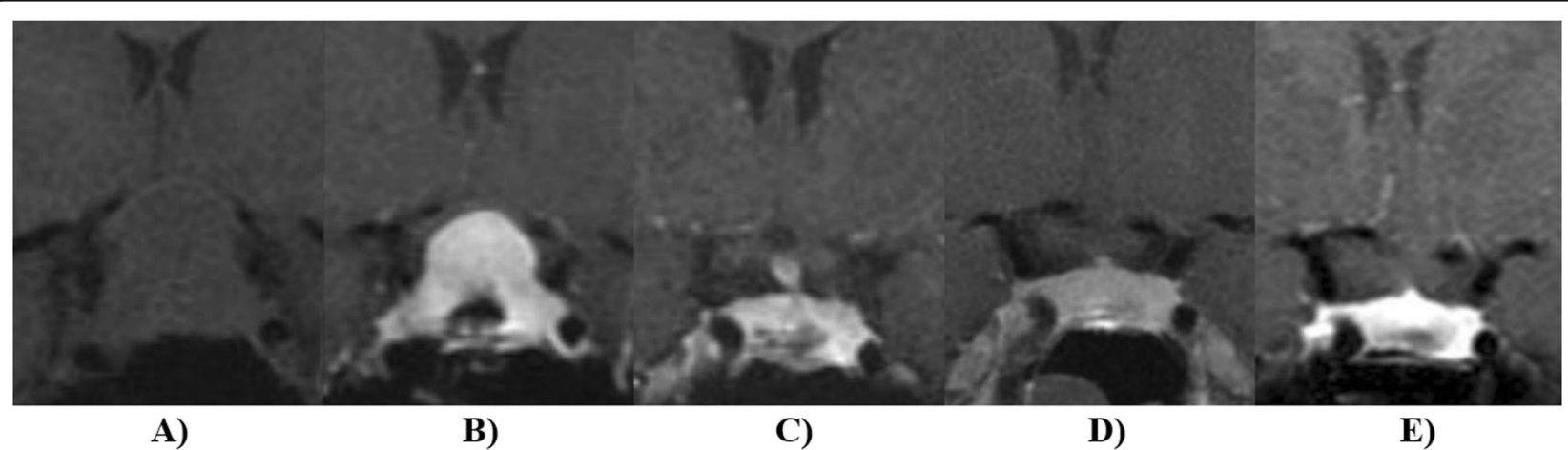

Fig. 1 Hypophysitis was diagnosed in a 30 year old during the late third trimester of pregnancy. The patient presented with 3 weeks of progression vision loss. Panel a depicts a coronal pre-contrast T1-weighted image of the pituitary. Transsphenoidal biopsy (Panel b) demonstrated lymphocytic hypophysitis and glucocorticoid therapy was begun with prednisone $60 \mathrm{mg}$ daily. Following delivery, the pituitary gland decreased in size (Panel c) and remained stable 2 months (Panel d) and 5 months (Panel e) after glucocorticoid taper and discontinuation 
dosages of glucocorticoids improve patient outcomes, higher doses do not appear to negatively impact the antitumor efficacy of immunotherapy or patient survival [6]. Improvement of pituitary function occurs in some patients following the resolution of hypophysitis; thyroidal and gonadal axis normalization occurs more frequently than adrenal recovery. The development of hypophysitis may be associated with improved patient survival in melanoma patients treated with Ipilimumab $[71,85]$.

\section{Pathogenesis}

The mechanisms underlying the development of hypophysitis are unknown. Other autoimmune diseases coexist in a portion of patients with hypophysitis. Unlike many of these other conditions, pituitary autoantigens in hypophysitis have not yet been clearly identified. Several candidates have been proposed, including growth hormone, pituitary gland specific factors $1 \mathrm{a}$ and 2 [86, 87], alpha-enolase and gamma-enolase [88, 89], secretogrannin II [90], chorionic somatomammotropin, CGI-99 [91], and corticotroph-specific transcription factor [92]. Measurements of antibodies to these proteins, however, do not have sufficient sensitivity and specificity to be diagnostically useful [16, 93]. Given the lack of clinically validated autoantigens, many studies have utilized indirect immunofluorescence (IIF) to detect the presence of pituitary autoantibodies. Ricciuti et al. systematically described methodologic limitations of IIF in the assessment of antipituitary antibodies, their potential effects on data interpretation, and methods to optimize results [94].

The pathogenic role of IgG4 in IgG4-related disease, including hypophysitis, is unclear, and it has been suggested that elevation of these antibodies may represent a bystander phenomenon [95]. IgG4 predominance often correlates with immune downregulation, in part due to its ability to participate in fragment antigen binding arm exchange [96].

Immunotherapy agents presumably can activate an autoimmune process directed against unidentified pituitary antigens. Pituitary autoantibodies were detected in patients who developed hypophysitis following treatment with Ipilimumab (a monoclonal antibody targeting CTLA-4), but these antibodies were not present in patients without hypophysitis. CTLA-4 is also expressed by the pituitary gland, and treatment with Ipilimumab may directly target pituitary cells via activation of the classical complement pathway and antibody-dependent cell-mediated cytotoxicity (ADCC) [97-99]. Pituitary CTLA-4 expression levels appear to vary widely [100] and may affect the risk of developing hypophysitis following treatment with Ipilimumab. In support of this hypothesis, hypophysitis has not been reported in patients with germline CTLA-4 mutations, although many of these patients had other severe autoimmune diseases which can occur following treatment with Ipilimumab [101, 102]. It is unknown whether PD-1 is expressed by the pituitary gland. Notably, anti-PD-1 agents are IgG4-based antibodies, which can not activate the classical complement pathway and are not effective mediators for ADCC [96, 103-105].

\section{Conclusions}

Currently, the diagnosis of primary hypophysitis typically requires a thorough evaluation for other potential neoplastic lesions, infiltrative diseases, infection, and systemic inflammatory processes plus histopathologic confirmation. In some cases, tissue biopsy may not be feasible. Cases of immunotherapy-associated hypophysitis and lymphocytic hypophysitis associated with pregnancy may potentially be diagnosed with some degree of confidence without surgery. Cranial nerve deficits due to mass effect from pituitary gland enlargement and severe headache are general indications for treatment with medical therapy and/or surgery. It is unclear whether active treatment improves clinical outcomes compared to supportive therapy for more mild cases of hypophysitis, and the therapies may be associated with side effects. Pituitary gland debulking rather than gross total resection is more commonly performed. Glucocorticoids (at variable dosages and duration) are the most frequent choice for medical therapy, though many other immunosuppressive agents have been utilized in the treatment of hypophysitis. Even when treatment is initially successful, disease recurrence is not uncommon. Radiation therapy appears promising, especially for refractory cases of hypophysitis, but the available published data consists of only a handful of patients.

Hypophysitis is an increasingly recognized but rare and poorly understood heterogeneous disease. The pathogenesis of primary hypophysitis is not yet known, and clinically validated disease markers have not been identified. In the absence of more detailed knowledge, various etiologic, morphologic, and histologic categories have been proposed, but the clinical utility of such schemas is limited. Inconsistent usage of terminology and variable diagnostic evaluations have also clouded data interpretation. Available studies are largely limited to retrospective series that likely include patients with diverse pathologies. Clinical investigation is constrained by the rarity of the disease. The acquisition of sufficient controlled prospective data will require multicenter collaboration. Until such investigations take place, optimal management strategies will remain largely undefined and controversial.

\section{Acknowledgements \\ None.}

\section{Funding}

None. 


\section{Availability of data and materials}

Not applicable.

\section{Competing interests}

None.

\section{Consent for publication}

Not applicable.

\section{Ethics approval and consent to participate}

Not applicable.

Received: 1 July 2016 Accepted: 26 August 2016

Published online: 06 September 2016

\section{References}

1. Chan WB, Cockram CS. Panhypopituitarism in association with interferon-alpha treatment. Singapore Med J. 2004:45:93-4.

2. Concha LB, Carlson HE, Heimann A, Lake-Bakaar GV, Paal AF. Interferon-induced hypopituitarism. Am J Med. 2003;114:161-3.

3. Ridruejo E, Christensen AF, Mando OG. Central hypothyroidism and hypophysitis during treatment of chronic hepatitis $C$ with pegylated interferon alpha and ribavirin. Eur J Gastroenterol Hepatol. 2006;18:693-4.

4. Sakane N, Yoshida T, Yoshioka K, Umekawa T, Kondo M, Shimatsu A. Reversible hypopituitarism after interferonalfa therapy. Lancet. 1995:345:1305

5. Tebben PJ, Atkinson JL, Scheithauer BW, Erickson D. Granulomatous adenohypophysitis after interferon and ribavirin therapy. Endocr Pract. 2007;13:169-75.

6. Faje A. Immunotherapy and hypophysitis: clinical presentation, treatment, and biologic insights. Pituitary. 2016;19:82-92.

7. Albini $\mathrm{CH}$, MacGillivray MH, Fisher JE, Voorhess ML, Klein DM. Triad of hypopituitarism, granulomatous hypophysitis, and ruptured Rathke's cleft cyst. Neurosurgery. 1988;22:133-6.

8. Daikokuya H, Inoue Y, Nemoto Y, Tashiro T, Shakudo M, Ohata K. Rathke's cleft cyst associated with hypophysitis: MRI. Neuroradiology. 2000:42:532-4.

9. Wearne MJ, Barber PC, Johnson AP. Symptomatic Rathke's cleft cyst with hypophysitis. Br J Neurosurg. 1995;9:799-803.

10. Hama S, Arita K, Tominaga A, Yoshikawa M, Eguchi K, Sumida M, Inai K, Nishisaka T, Kurisu K. Symptomatic Rathke's cleft cyst coexisting with central diabetes insipidus and hypophysitis: case report. Endocr J. 1999:46:187-92.

11. Puchner MJ, Ludecke DK, Saeger W. The anterior pituitary lobe in patients with cystic craniopharyngiomas: three cases of associated lymphocytic hypophysitis. Acta Neurochir (Wien). 1994;126:38-43.

12. McConnon JK, Smyth HS, Horvath E. A case of sparsely granulated growth hormone cell adenoma associated with lymphocytic hypophysitis. J Endocrinol Invest. 1991:14:691-6.

13. Jenkins PJ, Chew SL, Lowe DG, Afshart F, Charlesworth M, Besser GM, Was JA. Lymphocytic hypophysitis: unusual features of a rare disorder. Clin Endocrinol (Oxf). 1995:42:529-34

14. Moskowitz SI, Hamrahian A, Prayson RA, Pineyro M, Lorenz RR, Weil RJ. Concurrent lymphocytic hypophysitis and pituitary adenoma. Case report and review of the literature. J Neurosurg. 2006;105:309-14.

15. Holck S, Laursen H. Prolactinoma coexistent with granulomatous hypophysitis. Acta Neuropathol. 1983;61:253-7.

16. Caturegli P, Lupi I, Landek-Salgado M, Kimura H, Rose NR. Pituitary autoimmunity: 30 years later. Autoimmun Rev. 2008;7:631-7.

17. Ahmed SR, Aiello DP, Page R, Hopper K, Towfighi J, Santen RJ. Necrotizing infundibulo-hypophysitis: a unique syndrome of diabetes insipidus and hypopituitarism. J Clin Endocrinol Metab. 1993:76:1499-504.

18. Gutenberg A, Caturegli P, Metz I, Martinez R, Mohr A, Bruck W, Rohde V. Necrotizing infundibulo-hypophysitis: an entity too rare to be true? Pituitary. 2012:15:202-8

19. Beressi N, Beressi JP, Cohen R, Modigliani E. Lymphocytic hypophysitis. A review of 145 cases. Ann Med Interne (Paris). 1999:150:327-41.

20. Hunn BH, Martin WG, Simpson Jr S, McLean CA. Idiopathic granulomatous hypophysitis: a systematic review of 82 cases in the literature. Pituitary. 2014;17:357-65.

21. Doniach I, Wright EA. Two cases of giant-cell granuloma of the pituitary gland. J Pathol Bacteriol. 1951;63:69-79.
22. Folkerth RD, Price Jr DL, Schwartz M, Black PM, De Girolami U. Xanthomatous hypophysitis. Am J Surg Pathol. 1998:22:736-41.

23. Hanna B, Li YM, Beutler T, Goyal P, Hall WA. Xanthomatous hypophysitis J Clin Neurosci. 2015;22:1091-7.

24. Leporati P, Landek-Salgado MA, Lupi I, Chiovato L, Caturegli P. IgG4-related hypophysitis: a new addition to the hypophysitis spectrum. J Clin Endocrinol Metab. 2011;96:1971-80.

25. Caturegli P, Iwama S. From Japan with love: another tessera in the hypophysitis mosaic. J Clin Endocrinol Metab. 2013;98:1865-8.

26. Shimatsu A, Oki Y, Fujisawa I, Sano T. Pituitary and stalk lesions (infundibulohypophysitis) associated with immunoglobulin G4-related systemic disease: an emerging clinical entity. Endocr J. 2009;56:1033-41.

27. Caturegli P, Newschaffer C, Olivi A, Pomper MG, Burger PC, Rose NR. Autoimmune hypophysitis. Endocr Rev. 2005;26:599-614.

28. Imber BS, Lee HS, Kunwar S, Blevins LS, Aghi MK. Hypophysitis: a singlecenter case series. Pituitary. 2015;18:630-41.

29. Buxton N, Robertson I. Lymphocytic and granulocytic hypophysitis: a single centre experience. Br J Neurosurg. 2001;15:242-5. discussion 245-246.

30. Sautner D, Saeger W, Ludecke DK, Jansen V, Puchner MJ. Hypophysitis in surgical and autoptical specimens. Acta Neuropathol. 1995;90:637-44.

31. Leung GK, Lopes MB, Thorner MO, Vance ML, Laws Jr ER. Primary hypophysitis: a single-center experience in 16 cases. J Neurosurg. 2004;101:262-71.

32. Honegger J, Fahlbusch R, Bornemann A, Hensen J, Buchfelder M, Muller M, Nomikos P. Lymphocytic and granulomatous hypophysitis: experience with nine cases. Neurosurgery. 1997:40:713-22. discussion 722-713.

33. Goudie RB, Pinkerton PH. Anterior hypophysitis and Hashimoto's disease in a young woman. J Pathol Bacteriol. 1962;83:584-5.

34. Brissaud HH, Gougerot H, Gy A. Nevrite localised avec troubles trophiques a la suite de coupure de pouce. Rev Neurol. 1908;13:645.

35. Simmonds M. U* ber das Vorkommen von Riesenzellen in der Hypophyse. Virchows Arch. 1917:223(3):281-90

36. van der Vliet HJ, Perenboom RM. Multiple pseudotumors in IgG4-associated multifocal systemic fibrosis. Ann Intern Med. 2004;141:896-7.

37. Guay AT, Agnello V, Tronic BC, Gresham DG, Freidberg SR. Lymphocytic hypophysitis in a man. J Clin Endocrinol Metab. 1987;64:631-4.

38. Levine SN, Benzel EC, Fowler MR, Shroyer 3rd JV, Mirfakhraee M. Lymphocytic adenohypophysitis: clinical, radiological, and magnetic resonance imaging characterization. Neurosurgery. 1988;22:937-41.

39. Hoshimaru M, Hashimoto $\mathrm{N}$, Kikuchi H. Central diabetes insipidus resulting from a nonneoplastic tiny mass lesion localized in the neurohypophyseal system. Surg Neurol. 1992:38:1-6.

40. Gellner V, Kurschel S, Scarpatetti M, Mokry M. Lymphocytic hypophysitis in the pediatric population. Childs Nerv Syst. 2008;24:785-92.

41. Landek-Salgado MA, Gutenberg A, Lupi I, Kimura H, Mariotti S, Rose NR, Caturegli P. Pregnancy, postpartum autoimmune thyroiditis, and autoimmune hypophysitis: intimate relationships. Autoimmun Rev. 2010;9:153-7.

42. Honegger J, Schlaffer S, Menzel C, Droste M, Werner S, Elbelt U, Strasburger C, Stormann S, Kuppers A, Streetz-van der Werf C, et al. Diagnosis of primary hypophysitis in Germany. J Clin Endocrinol Metab. 2015;100:3841-9.

43. Khare S, Jagtap VS, Budyal SR, Kasaliwal R, Kakade HR, Bukan A, Sankhe S, Lila AR, Bandgar T, Menon PS, Shah NS. Primary (autoimmune) hypophysitis: a single centre experience. Pituitary. 2015;18:16-22.

44. Peruzzotti-Jametti L, Strambo D, Sangalli F, De Bellis A, Comi G, Sessa M. Bilateral intracavernous carotid artery occlusion caused by invasive lymphocytic hypophysitis. J Stroke Cerebrovasc Dis. 2012;21:918. e919-911.

45. Ikeda J, Kuratsu J, Miura M, Kai Y, Ushio Y. Lymphocytic adenohypophysitis accompanying occlusion of bilateral internal carotid arteries-case report. Neurol Med Chir (Tokyo). 1990;30:346-9.

46. Melgar MA, Mariwalla N, Gloss DS, Walsh JW. Recurrent lymphocytic hypophysitis and bilateral intracavernous carotid artery occlusion. an observation and review of the literature. Neurol Res. 2006;28:177-83.

47. Minakshi B, Alok S, Hillol KP. Lymphocytic hypophysitis presenting as pituitary apoplexy in a male. Neurol India. 2005;53:363-4.

48. Husain Q, Zouzias A, Kanumuri W, Eloy JA, Liu JK. Idiopathic granulomatous hypophysitis presenting as pituitary apoplexy. J Clin Neurosci. 2014:21:510-2.

49. Kravarusic J, Molitch ME. Lymphocytic hypophysitis and other inflammatory conditions of the pituitary. In: Oxford Textbook of Endocrinology and Diabetes. New York: Oxford University Press; 2011. p. 259-66. 
50. Turcu AF, Erickson BJ, Lin E, Guadalix S, Schwartz K, Scheithauer BW, Atkinson JL, Young Jr WF. Pituitary stalk lesions: the Mayo Clinic experience. J Clin Endocrinol Metab. 2013;98:1812-8.

51. Cives M, Simone V, Rizzo FM, Dicuonzo F, Cristallo Lacalamita M, Ingravallo G, Silvestris F, Dammacco F. Erdheim-Chester disease: a systematic review. Crit Rev Oncol Hematol. 2015:95:1-11.

52. Monsereenusorn C, Rodriguez-Galindo C. Clinical characteristics and treatment of langerhans cell histiocytosis. Hematol Oncol Clin North Am. 2015;29:853-73.

53. Strowd RE, Burger P, Holdhoff M, Kleinberg L, Okun MS, Olivi A, Pardo-Villamizar C, Schiess N. Steroid-responsive intracranial germinoma presenting as Holmes' tremor: importance of a tissue diagnosis. J Clin Neurosci. 2015;22:911-3.

54. Si SJ, Khatua S, Dhall G, Nelson MD, Gonzalez-Gomez I, Finlay JL. Regression of primary central nervous system germinoma after dexamethasone administration: a case report. Pediatr Hematol Oncol. 2010;27:237-43.

55. Mascalchi M, Roncaroli F, Salvi F, Frank G. Transient regression of an intracranial germ cell tumour after intravenous steroid administration: a case report. J Neurol Neurosurg Psychiatry. 1998;64:670-2.

56. Gutenberg A, Bell JJ, Lupi I, Tzou SC, Landek-Salgado MA, Kimura H, Su J, Karaviti LP, Salvatori R, Caturegli P. Pituitary and systemic autoimmunity in a case of intrasellar germinoma. Pituitary. 2011;14:388-94.

57. Konno S, Oka H, Utsuki S, Kondou K, Tanaka S, Fujii K, Yagishita S. Germinoma with a granulomatous reaction. Problems of differential diagnosis. Clin Neuropathol. 2002;21:248-51.

58. Endo T, Kumabe T, Ikeda H, Shirane R, Yoshimoto T. Neurohypophyseal germinoma histologically misidentified as granulomatous hypophysitis. Acta Neurochir (Wien). 2002;144:1233-7.

59. Gutenberg A, Larsen J, Lupi I, Rohde V, Caturegli P. A radiologic score to distinguish autoimmune hypophysitis from nonsecreting pituitary adenoma preoperatively. AJNR Am J Neuroradiol. 2009;30:1766-72.

60. Khosroshahi A, Cheryk LA, Carruthers MN, Edwards JA, Bloch DB, Stone JH. Brief Report: spuriously low serum lgG4 concentrations caused by the prozone phenomenon in patients with IgG4-related disease. Arthritis Rheumatol. 2014;66:213-7.

61. Wallace ZS, Deshpande V, Mattoo H, Mahajan VS, Kulikova M, Pillai S, Stone JH. IgG4-Related Disease: Clinical and Laboratory Features in One Hundred Twenty-Five Patients. Arthritis Rheumatol. 2015;67:2466-75.

62. Chang SY, Keogh KA, Lewis JE, Ryu JH, Cornell LD, Garrity JA, Yi ES. IgG4-positive plasma cells in granulomatosis with polyangiitis (Wegener's): a clinicopathologic and immunohistochemical study on 43 granulomatosis with polyangiitis and 20 control cases. Hum Pathol. 2013;44:2432-7.

63. Nishioka H, Shibuya M, Haraoka J. Immunohistochemical study for IgG4-positive plasmacytes in pituitary inflammatory lesions. Endocr Pathol. 2010;21:236-41

64. Bando H, Iguchi G, Fukuoka H, Taniguchi M, Kawano S, Saitoh M, Yoshida K, Matsumoto R, Suda K, Nishizawa H, et al. A diagnostic pitfall in IgG4-related hypophysitis: infiltration of IgG4-positive cells in the pituitary of granulomatosis with polyangiitis. Pituitary. 2015;18:722-30.

65. Ohkubo Y, Sekido T, Takeshige K, Ishi H, Takei M, Nishio S, Yamazaki M, Komatsu M, Kawa S, Suzuki S. Occurrence of IgG4-related hypophysitis lacking IgG4-bearing plasma cell infiltration during steroid therapy. Intern Med. 2014;53:753-7.

66. Deshpande V, Zen Y, Chan JK, Yi EE, Sato Y, Yoshino T, Kloppel G, Heathcote $J G$, Khosroshahi A, Ferry JA, et al. Consensus statement on the pathology of IgG4-related disease. Mod Pathol. 2012;25:1181-92.

67. Bando $H$, Iguchi $G$, Fukuoka $H$, Taniguchi M, Yamamoto M, Matsumoto $R$, Suda K, Nishizawa H, Takahashi M, Kohmura E, Takahashi Y. The prevalence of IgG4-related hypophysitis in 170 consecutive patients with hypopituitarism and/or central diabetes insipidus and review of the literature. Eur J Endocrinol. 2014;170:161-72.

68. Tauziede-Espariat A, Polivka M, Bouazza S, Decq P, Robert G, Laloi-Michelin M, Adle-Biassette $\mathrm{H}$. The prevalence of lgG4-positive plasma cells in hypophysitis: a possible relationship to IgG4-related disease. Clin Neuropathol. 2015;34:181-92

69. Ngaosuwan K, Trongwongsa T, Shuangshoti S. Clinical course of IgG4related hypophysitis presenting with focal seizure and relapsing lymphocytic hypophysitis. BMC Endocr Disord. 2015;15:64.

70. Sosa GA, Bell S, Christiansen SB, Pietrani M, Glerean M, Loto M, Lovazzano S, Carrizo A, Ajler P, Fainstein Day P. Histologically confirmed isolated lgG4-related hypophysitis: two case reports in young women. Endocrinol Diabetes Metab Case Rep. 2014;2014:140062
71. Faje AT, Sullivan R, Lawrence D, Tritos NA, Fadden R, Klibanski A, Nachtigall L. Ipilimumab-induced hypophysitis: a detailed longitudinal analysis in a large cohort of patients with metastatic melanoma. J Clin Endocrinol Metab. 2014;99:4078-85.

72. Jennings MT, Gelman R, Hochberg F. Intracranial germ-cell tumors: natural history and pathogenesis. J Neurosurg. 1985;63:155-67.

73. Howarth DM, Gilchrist GS, Mullan BP, Wiseman GA, Edmonson JH, Schomberg PJ. Langerhans cell histiocytosis: diagnosis, natural history, management, and outcome. Cancer. 1999;85:2278-90.

74. Stalemark H, Laurencikas E, Karis J, Gavhed D, Fadeel B, Henter Jl. Incidence of Langerhans cell histiocytosis in children: a population-based study. Pediatr Blood Cancer. 2008;51:76-81.

75. Honegger J, Buchfelder M, Schlaffer S, Droste M, Werner S, Strasburger C, Stormann S, Schopohl J, Kacheva S, Deutschbein T, et al. Treatment of primary hypophysitis in Germany. J Clin Endocrinol Metab. 2015:100:3460-9.

76. Lupi I, Manetti L, Raffaelli V, Lombardi M, Cosottini M, lannelli A, Basolo F, Proietti A, Bogazzi F, Caturegli P, Martino E. Diagnosis and treatment of autoimmune hypophysitis: a short review. J Endocrinol Invest. 2011:34:e245-252.

77. Schreckinger M, Francis T, Rajah G, Jagannathan J, Guthikonda M, Mittal S. Novel strategy to treat a case of recurrent lymphocytic hypophysitis using rituximab. J Neurosurg. 2012;116:1318-23.

78. Xu C, Ricciuti A, Caturegli P, Keene CD, Kargi AY. Autoimmune lymphocytic hypophysitis in association with autoimmune eye disease and sequential treatment with infliximab and rituximab. Pituitary. 2015;18:441-7.

79. Lecube A, Francisco G, Rodriguez D, Ortega A, Codina A, Hernandez C, Simo R. Lymphocytic hypophysitis successfully treated with azathioprine: first case report. J Neurol Neurosurg Psychiatry. 2003;74:1581-3.

80. Li HT, Wang ST, Qiu MC. Gynecomastia, obesity and underdeveloped testis and penis: suspected hypophysitis successfully cured with low dose of cyclosporine A. Chin Med J (Engl). 2009;122:2791-3.

81. Ward L, Paquette J, Seidman E, Huot C, Alvarez F, Crock P, Delvin E, Kampe $\mathrm{O}$, Deal C. Severe autoimmune polyendocrinopathy-candidiasis-ectodermal dystrophy in an adolescent girl with a novel AIRE mutation: response to immunosuppressive therapy. J Clin Endocrinol Metab. 1999;84:844-52.

82. Louvet C, Maqdasy S, Tekath M, Grobost V, Rieu V, Ruivard M, Le Guenno G. Infundibuloneurohypophysitis associated with sjogren syndrome successfully treated with mycophenolate mofetil: a case report. Medicine (Baltimore). 2016;95:e3132.

83. Ray DK, Yen CP, Vance ML, Laws ER, Lopes B, Sheehan JP. Gamma knife surgery for lymphocytic hypophysitis. J Neurosurg. 2010;112:118-21.

84. Selch MT, DeSalles AA, Kelly DF, Frighetto L, Vinters HV, Cabatan-Awang C, Wallace RE, Solberg TD. Stereotactic radiotherapy for the treatment of lymphocytic hypophysitis. Report of two cases. J Neurosurg. 2003;99:591-6.

85. Eatrides J, Weber J, Egan K, Acierno M, Schell M, Lillienfeld H, Creelan B: Autoimmune hypophysitis is a marker of favorable outcome during treatment of melanoma with ipilimumab. AACR: Advances in Melanoma: From Biology to Therapy 2014, abstract.

86. Takao T, Nanamiya W, Matsumoto R, Asaba K, Okabayashi T, Hashimoto K. Antipituitary antibodies in patients with lymphocytic hypophysitis. Horm Res. 2001;55:288-92.

87. Tanaka S, Tatsumi Kl, Kimura M, Takano T, Murakami Y, Takao T, Hashimoto K, Kato Y, Amino N. Detection of autoantibodies against the pituitary-specific proteins in patients with lymphocytic hypophysitis. Eur J Endocrinol. 2002;147:767-75

88. Tanaka S, Tatsumi Kl, Takano T, Murakami Y, Takao T, Yamakita N, Tahara S, Teramoto A, Hashimoto K, Kato Y, Amino N. Anti-alpha-enolase antibodies in pituitary disease. Endocr J. 2003;50:697-702.

89. O'Dwyer DT, Clifton V, Hall A, Smith R, Robinson PJ, Crock PA. Pituitary autoantibodies in lymphocytic hypophysitis target both gamma- and alphaEnolase - a link with pregnancy? Arch Physiol Biochem. 2002;110:94-8.

90. Bensing S, Hulting AL, Hoog A, Ericson K, Kampe O. Lymphocytic hypophysitis: report of two biopsy-proven cases and one suspected case with pituitary autoantibodies. J Endocrinol Invest. 2007:30:153-62.

91. Lupi I, Broman KW, Tzou SC, Gutenberg A, Martino E, Caturegli P. Novel autoantigens in autoimmune hypophysitis. Clin Endocrinol (Oxf). 2008:69:269-78.

92. Smith CJ, Bensing S, Burns C, Robinson PJ, Kasperlik-Zaluska AA, Scott RJ, Kampe O, Crock PA. Identification of TPIT and other novel autoantigens in lymphocytic hypophysitis: immunoscreening of a pituitary cDNA library and development of immunoprecipitation assays. Eur J Endocrinol. 2012;166:391-8. 
93. Falorni A, Minarelli V, Bartoloni E, Alunno A, Gerli R. Diagnosis and classification of autoimmune hypophysitis. Autoimmun Rev. 2014;13:412-6.

94. Ricciuti A, De Remigis A, Landek-Salgado MA, De Vincentiis L, Guaraldi F, Lupi I, Iwama S, Wand GS, Salvatori R, Caturegli P. Detection of pituitary antibodies by immunofluorescence: approach and results in patients with pituitary diseases. J Clin Endocrinol Metab. 2014;99:1758-66.

95. Wallace ZS, Stone JH. An update on IgG4-related disease. Curr Opin Rheumatol. 2015;27:83-90.

96. Vidarsson G, Dekkers G, Rispens T. IgG subclasses and allotypes: from structure to effector functions. Front Immunol. 2014;5:520.

97. Iwama S, De Remigis A, Callahan MK, Slovin SF, Wolchok JD, Caturegli P. Pituitary expression of CTLA-4 mediates hypophysitis secondary to administration of CTLA-4 blocking antibody. Sci Transl Med. 2014:6:230ra245.

98. Romano E, Kusio-Kobialka M, Foukas PG, Baumgaertner P, Meyer C, Ballabeni $P$, Michielin O, Weide B, Romero $P$, Speiser DE. Ipilimumab-dependent cell-mediated cytotoxicity of regulatory $T$ cells ex vivo by nonclassical monocytes in melanoma patients. Proc Natl Acad Sci U S A. 2015;112:6140-5.

99. Laurent S, Queirolo P, Boero S, Salvi S, Piccioli P, Boccardo S, Minghelli S, Morabito A, Fontana V, Pietra G, et al. The engagement of CTLA-4 on primary melanoma cell lines induces antibody-dependent cellular cytotoxicity and TNF-alpha production. J Transl Med. 2013;11:108.

100. Faje A, Ma J, Wang X, Swearingen B, Tritos NA, Nachtigall L, Zhang X, Klibanski A: Cytotoxic T-lymphocyte antigen-4 gene expression in human pituitary adenomas. ENDO 2015, abstract.

101. Kuehn HS, Ouyang W, Lo B, Deenick EK, Niemela JE, Avery DT, Schickel JN, Tran DQ, Stoddard J, Zhang Y, et al. Immune dysregulation in human subjects with heterozygous germline mutations in CTLA4. Science. 2014:345:1623-7.

102. Schubert D, Bode C, Kenefeck R, Hou TZ, Wing JB, Kennedy A, Bulashevska A, Petersen BS, Schaffer AA, Gruning BA, et al. Autosomal dominant immune dysregulation syndrome in humans with CTLA4 mutations. Nat Med. 2014:20:1410-6.

103. Garred P, Michaelsen TE, Aase A. The IgG subclass pattern of complement activation depends on epitope density and antibody and complement concentration. Scand J Immunol. 1989;30:379-82.

104. Michaelsen TE, Garred P, Aase A. Human lgG subclass pattern of inducing complement-mediated cytolysis depends on antigen concentration and to a lesser extent on epitope patchiness, antibody affinity and complement concentration. Eur J Immunol. 1991;21:11-6.

105. Bruhns P, lannascoli B, England P, Mancardi DA, Fernandez N, Jorieux S, Daeron M. Specificity and affinity of human Fcgamma receptors and their polymorphic variants for human IgG subclasses. Blood. 2009;113:3716-25.

\section{Submit your next manuscript to BioMed Central and we will help you at every step:}

- We accept pre-submission inquiries

- Our selector tool helps you to find the most relevant journal

- We provide round the clock customer support

- Convenient online submission

- Thorough peer review

- Inclusion in PubMed and all major indexing services

- Maximum visibility for your research

Submit your manuscript at www.biomedcentral.com/submit 